\title{
REKLAMASI DAN RESTORASI EKOLOGI KAWASAN TANJUNG API - API PROVINSI SUMATERA SELATAN
}

\author{
ECOLOGICAL RECLAMATATION AND RESTORATION OF \\ TANJUNG API - API SOUTH SUMATERA PROVINCE
}

\author{
Reflis $\left.{ }^{1},{ }^{2}\right)$ \\ ${ }^{1}$ Student, Doctoral Study Programe in Environmental Science, Sriwijaya \\ University, Palembang-Indonesia \\ ${ }^{2}$ Jurusan Sosial Ekonomi Pertanian, Fakultas Pertanian Universitas Bengkulu \\ Email: reflis@yahoo.com
}

\begin{abstract}
Damage to mangrove forests should be stopped by holding conservation activities, even restore to reorganize. These activities not only protect and preserve the species as well as providing a tourist attraction (ecotourism) but should also serve to improve the socio-economic conditions of the surrounding community in the context of sustainable development. This paper is to explain the problems of environmental degradation, especially the large-scale exploitation of mangrove forests in the region of Tanjung ApiApi Reclamation, Banyuasin regency of South Sumatra province. The method used is a review of research papers and reports on Reclamation area of Tanjung Api-Api and management of Special Economic Zones (SEZ). Reclamation activities Tanjung Api-Api is basically not recommended because it lowers the quality of mangrove Environment and Watershed Musi, but the public interest by taking into account all the benefits that this can be continued reclamation of origin according to applicable regulations and pay attention to aspects related impact and benefits. Damage to ecosystems due to reclamation Tanjung Api-Api quite alarming, therefore it is necessary to the recovery through the restoration of mangrove forest and watershed restoration Musi integrated. Ecological restoration is expected to restore the function and role of the mangrove ecosystem and watershed Musi.
\end{abstract}

Keywords: mangrove forests, reclamation, restoration and sustainable development

\section{PENDAHULUAN}

Pemanfaatan sumberdaya alam harus dilakukan kajian terlebih dahulu tentang potensi dan dampaknya terhadap lingkungan, sehingga dapat menjaga kelestariannya. Dari perspektif ekologis, pelaksanaan pembangunan berkelanjutan mensyaratkan resultante laju pembangunan ekonomi hendaknya tidak melebihi daya dukung lingkungan yang menopangnya. Artinya, total dampak lingkungan (baik dalam bentuk pencemaran, overexploitation sumberdaya alam, perubahan bentang alam maupun perubahan 
proses ekologis) akibat kegiatan pembangunan harus diupayakan tidak melebihi kemampuan sistem alam (ekosistem).

Woinarski (2002), memasukkan dimensi ekologis ke dalam pembangunan sosial ekonomi yang memerlukan pendekatan antisipatif (anticipatory approach) dan tidak menggunakan pendekatan pembangunan bersifat reaktif (react and cure). Salah satu cara sistematis untuk menerapkan pendekatan antisipatif dalam mengharmoniskan pertimbangan ekologis dan kepentingan pembangunan sosial ekonomi adalah melalui AMDAL (Analisis Mengenai Dampak Lingkungan) yang mengacu pada peraturan perundangan yang berlaku. Huda (2013), menjelaskan bahwa AMDAL merupakan syarat mutlak untuk bisa dilaksanakannya reklamasi, karena studi AMDAL ini akan melihat manfaat dan dampak yang ditimbulkan dari proyek tersebut. Apabila hasil studi AMDAL menunjukkan kemungkinan akan timbulnya dampak negatif dari pelaksanaan kegiatan reklamasi tersebut, maka sudah selayaknya perencanaan reklamasi tersebut tidak dapat dilakukan.

Kawasan reklamasi Tanjung Api-Api (TAA), merupakan ekosistem yang terletak di daerah pesisir timur Sumatera Selatan (Sumsel) berada di Kabupaten Banyuasin. Daerah ini dikelilingi oleh hutan bakau. Fungsi utama hutan bakau atau mangrove adalah untuk melindungi garis pantai dari abrasi atau pengikisan serta meredam gelombang besar termasuk tsunami. Keberagaman biota yang terdapat pada kawasan reklamasi Tanjung Api-Api menjadi hal penting dalam perputaran ekosistem pada hutan bakau karena wilayahnya yang saling berkaitan. Adanya tanaman bakau ini menjadikan sepanjang pesisir Tanjung Api-Api sebagai Kawasan Pantai Berhutan Bakau. Berdasarkan Keputusan Presiden Republik Indonesia No. 32 tahun 1990 tentang Pengelolaan Kawasan Lindung, Kawasan Pantai Berhutan Bakau adalah kawasan pesisir laut yang merupakan habitat alami hutan bakau (mangrove) yang berfungsi memberi perlindungan kepada perikehidupan pantai dan lautan. Dan pada Pasal 6 (enam) dijelaskan bahwa kawasan pantai berhutan bakau termasuk salah satu dari kawasan suaka alam dan cagar budaya.

Gubernur Sumatera Selatan (Palembang Pos, 2013), telah melaksanakan pembangunan kawasan reklamasi Tanjung Api-Api untuk menjadi Kawasan Ekonomi Khusus Tanjung Api-Api (KEK TAA), dengan melakukan reklamasi pantai untuk membuat pelabuhan di Tanjung Carat. Tujuan dari rencana tersebut adalah untuk mendukung program MP3EI (Masterplan Percepatan dan Perluasan Pembangunan Ekonomi Indonesia). Program pemerintah tersebut merumuskan bahwa Sumatera Selatan dan Povinsi lain di Sumatera termasuk dalam salah satu dari 6 (enam) koridor ekonomi yang bertujuan sebagai pintu gerbang produksi dan pengolahan hasil bumi dan lumbung energi nasional. Enam koridor ekonomi nasional dalam MP3EI terlihat pada Gambar 1.

58 | Reflis; Reklamasi dan Restorasi Ekologi Tanjung Api - api ... 


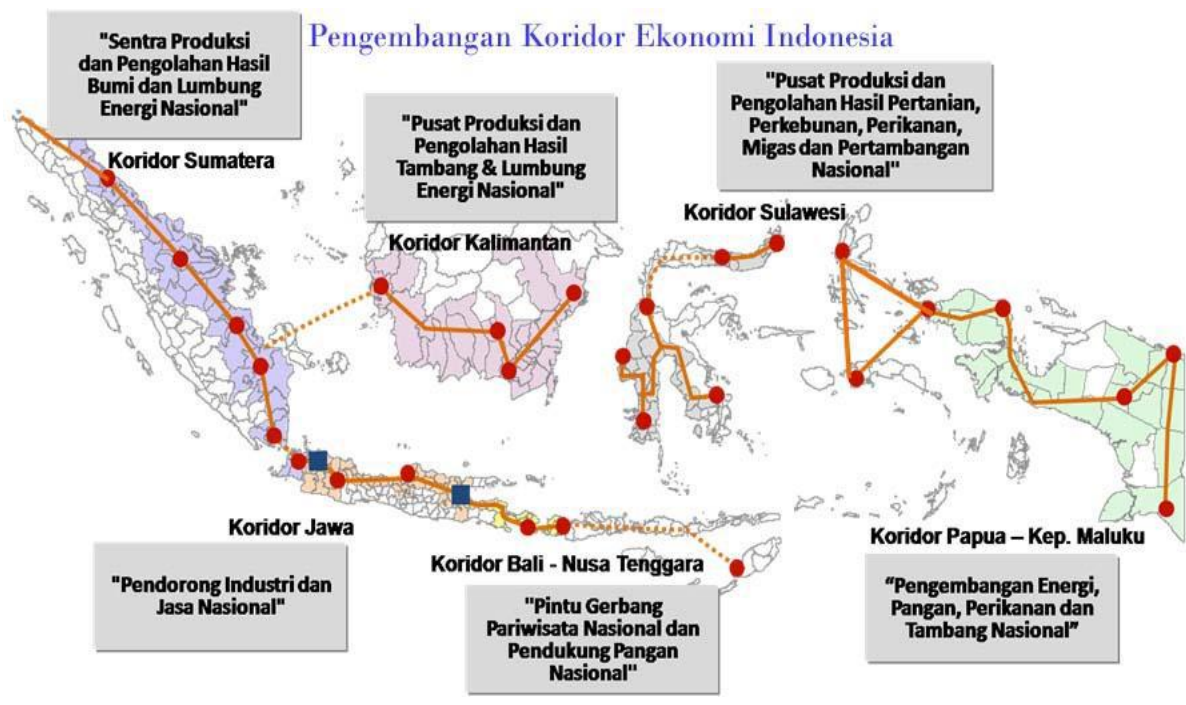

\section{Gambar 1}

Koridor Ekonomi Indonesia dalam MP3EI (sumber : Widjanarko, 2013)

Bertitik tolak dari latar belakang di atas tujuan dari penelitian ini adalah untuk: 1) Mengkaji dampak reklamasi kawasan Tanjung Api-Api Kabupaten Banyuasin Provinsi Sumatera Selatan terhadap kualitas lingkungan, khususnya hutan bakau (mangrove) dan Daerah Aliran Sungai (DAS) Musi bagian hilir; 2) Mengkaji upaya-upaya yang harus dilakukan untuk mengatasi dampak dari reklamasi kawasan Tanjung Api-Api Kabupaten Banyuasin Provinsi Sumatera Selatan.

Kegiatan reklamasi pantai sangat memungkinkan timbulnya dampak terhadap lingkungan. Untuk menilai dampak tersebut bisa dibedakan dari tahapan yang dilaksanakan dalam proses reklamasi, yaitu: Pertama, tahap pra konstruksi, antara lain meliputi kegiatan survei teknis dan lingkungan, pemetaan dan pembuatan pra rencana, perizinan, pembuatan rencana detail atau teknis. Kedua, tahap konstruksi, kegiatan mobilisasi tenaga kerja, pengambilan material urug, transportasi material urug, proses pengurugan. Ketiga, tahap pasca konstruksi, yaitu kegiatan demobilisasi peralatan dan juga tenaga kerja, pematangan lahan, pemeliharaan lahan (Huda,2013).

Basri dan Kasuri (2013) menyatakan bahwa untuk melihat dampak tersebut, maka wilayah yang berpeluang terkena adalah: Pertama, hilangnya wilayah pantai yang merupakan ruang publik bagi masyarakat. Dari sisi lingkungan banyak biota laut yang mati baik flora maupun fauna karena timbunan tanah urug sehingga mempengaruhi ekosistem yang sudah ada. Kedua, sistem hidrologi gelombang air laut yang jatuh ke pantai akan berubah dari alaminya. Berubahnya alur air akan mengakibatkan daerah diluar reklamasi 
akan mendapat limpahan air yang banyak sehingga kemungkinan akan terjadinya abrasi, tergerus atau mengakibatkan terjadinya banjir atau rob karena genangan air yang banyak dan lama. Ketiga, aspek sosialnya, kegiatan masyarakat di wilayah pantai sebagian besar adalah sebagai petani tambak, nelayan ataupun buruh. Dengan adanya reklamasi ini akan mempengaruhi ikan yang ada di laut, sehingga nanti akan berakibat pada menurunnya pendapatan mereka yang tentunya menggantungkan hidup kepada laut. Selanjutnya adalah aspek ekologi, kondisi ekosistem di wilayah pantai yang kaya akan keanekaragaman hayati sangat mendukung fungsi pantai sebagai penyangga daratan. Ekosistem perairan pantai sangat rentan terhadap perubahan sehingga apabila terjadi perubahan baik secara alami maupun rekayasa akan mengakibatkan berubahnya keseimbangan ekosistem. Ketidakseimbangan ekosistem perairan pantai dalam waktu yang relatif lama ini akan berakibat pada kerusakan ekosistem wilayah pantai, kondisi ini menyebabkan kerusakan pantai.

Sesuai dengan definisinya, maka reklamasi merupakan perbaikan infrastruktur wilayah guna meningkatkan manfaat sumber daya lahan baik dari segi lingkungan, dan sosial ekonomi. Menurut Modul Terapan Pedoman Perencanaan Tata Ruang Kawasan Reklamasi Pantai Peraturan Menteri Pekerjaan Umum No. 40/PRT/M/2007, pola ruang kawasan reklamasi pantai disusun dengan memperhatikan: 1) Keseimbangan antara rencana pemanfaatan lahan untuk kepentingan fungsi budidaya dan lahan untuk fungsi lindung dengan memperhatikan kelestarian lingkungan hidup yang mencakup sumber daya alam dan buatan; 2) Keseimbangan komposisi lahan pemanfaatan ruang antara ruang di daratan dengan perairan/tata biru/pantai; 3) Peruntukan kawasan reklamasi pantai harus dimanfaatkan secara efektif, menghargai signifikansi ruang perairan, ada kesinergisan pola ruang kawasan budidaya dengan lingkungan alami disekitarnya; 4) Pola ruang di sepanjang garis pantai yang merupakan wilayah garis sepadan pantai harus diarahkan menjadi ruang publik (jalan tepian pantai atau pun ruang terbuka) yang dapat diakses dan dinikmati publik; 5) Pola ruang kawasan diarahkan untuk mengakumulasi beberapa fungsi kawasan yang menghargai, menyatu dan memanfaatkan potensi pantai. Jaringan dan sistem infrastruktur/prasarana dirancang mengikuti pola struktur ruang kawasan reklamasi. Rencana Induk Sistem (RIS) kawasan reklamasi pantai tersebut harus terintegrasi dengan sistem perwilayahan (Basri dan Kasuri, 2013).

\section{METODE PENELITIAN}

Metode kajian dilakukan dengan studi literatur dan studi dokumentasi, yang dilakukan dengan penggunaan teori sebagai alat prediksi fenomena permasalahan yang berkaitan dengan reklamasi kawasan Tanjung Api-Api dan pengelolaan Kawasan Ekonomi Khusus (KEK). Penelitian ini dalam bentuk

60 | Reflis; Reklamasi dan Restorasi Ekologi Tanjung Api - api ... 
artikel ilmiah dan laporan dari lembaga terkait dan laporan Laboratorium Lingkungan Badan Lingkungan Hidup Provinsi Sumatera Selatan yang akan membahas semua aspek kelembagaan lingkungan hidup yang ada saat ini. Kelembagaan disini erat hubungannya dengan institusi baik pemerintah maupun produk perundang-undangan yang telah ditetapkan oleh pemerintah pusat maupun daerah. Adapun perundang-undangan yang berkaitan dengan lingkungan hidup dapat dibagi sesuai dengan hirarkinya adalah: UndangUndang (UU), Peraturan Pemerintah (PP), Keputusan Presiden (Keppres), Keputusan Menteri (Kepmen), Keputusan Kepala Bappedal, Peraturan Daerah (Perda), dan Keputusan Gubernur. Disamping itu juga ditinjau kepatuhan masyarakat terhadap lingkungan dan kemampuan aparat negara dalam menjerat pelanggar UU Lingkungan Hidup. Kelembagaan yang ada saat ini lebih efektif dalam melaksanakan pengelolaan lingkungan hidup, sehingga perlu dianalisis lebih lanjut. Disamping itu juga akan dilihat efektivitas dari program-program yang dijalankan pemerintah untuk menanggulangi dampak lingkungan, seperti Program Reklamasi kawasan.

\section{Lokasi Penelitian}

Dari beberapa isu penting pengelolaan sumberdaya alam dan reklamasi kawasan Tanjung Api-Api Kabupaten Banyuasin Provinsi Sumatera Selatan. Penulis tertarik untuk mengkaji khusus tentang reklamasi kawasan Tanjung Api-Api karena lokasi ini merupakan kawasan bagian hilir Daerah Aliran Sungai Musi dan kawasan konservasi berupa hutan bakau (mangrove) merupakan bagian dari ekosistem lahan basah (wetland).

\section{HASIL DAN PEMBAHASAN}

\section{Dampak Kawasan Reklamasi Tanjung Api-Api terhadap pembangunan berkelanjutan}

Berdasarkan Peraturan Pemerintah nomor 51 tahun 2014, wilayah Tanjung Api-Api (TAA) ditetapkan sebagai Kawasan Ekonomi Khusus (KEK). Kawasan Ekonomi Khusus Tanjung Api-Api memiliki luas 2.030 ha yang terletak dalam wilayah Desa Muara Sungsang dan Desa Teluk Payo, Kecamatan Banyuasin II, Kabupaten Banyuasin, Provinsi Sumatera Selatan. Salah satu infrastruktur penting untuk mendukung program KEK adalah Pelabuhan Tanjung Api-Api (PTAA). Pelabuhan ini berada di Muara Sungai Banyuasin, berfungsi sebagai moda transportasi air untuk mendukung aktivitas perekonomian berupa mobilitas manusia dan barang.

Untuk mencapai pembangunan berkelanjutan di kawasan reklamasi Tanjung Api-Api harus memenuhi tiga pilar yaitu aspek lingkungan, ekonomi dan sosial. Awalnya terjadi kecenderungan aktivitas manusia semata-mata terkait dengan ekonomi, selanjutnya dimulailah gagasan untuk pembangunan 
berkelanjutan yang menyeimbangkan aspek manusia, ekonomi dan lingkungan (Edwars, 2001 dalam Suganda, Yatmo, dan Atmodiwirjo, 2009). Pendekatan pada Gambar 2, menunjukkan adanya prinsip dalam memandang isu ekologi atau lingkungan. Diperlukan strategi perancangan wilayah yang memperhatikan aspek-aspek lingkungan, sosial, ekonomi secara seimbang dan dinamis, memperhatikan pembangunan spesifik lokal, serta bersifat tidak linier melainkan mengandung proses umpan balik (Suganda, Yatmo, dan Atmodiwirjo, 2009). Pada saat ini, terjadi kecenderungan bahwa aspek ekonomi lebih mendapat penekanan dibanding aspek sosial dan lingkungan. Terkait dengan kewenangan wilayah kabupaten Banyuasin atau Povinsi Sumatera Selatan dalam mengatur wilayahnya melalui otonomi daerah dan kecenderungan untuk menaikkan Pendapatan Asli Daerah (PAD) masingmasing. Akibatnya, setiap daerah dapat memanfaatkan sumberdaya alam yang ada tanpa adanya perencanaan kelestarian lingkungannya.

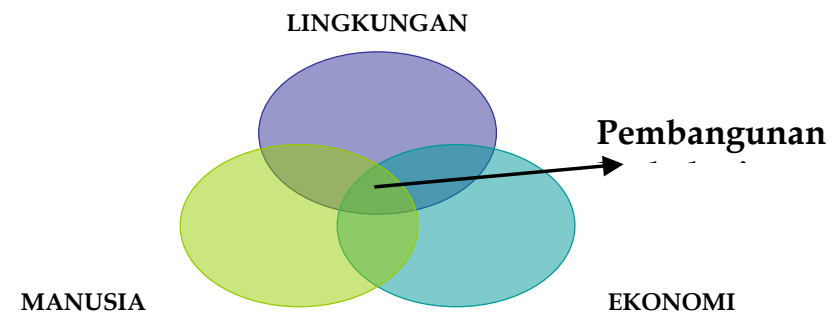

Gambar 2.

Konsep Pembangunan Berkelanjutan Edwars (2001) dalam Suganda, Yatmo, dan Atmodiwirjo (2009).

Kawasan reklamasi Tanjung Api-Api berhadapan langsung dengan Selat Bangka, dipengaruhi oleh gelombang pasang-surut (Pasut) dan faktor-faktor alam lainnya sehingga kawasan ini merupakan sistem alam yang dinamis. Di ujung DAS Musi bagian hilir ini terdapat Muara Sungai Banyuasin (MSB) sebagai saluran akhir Sungai Lalan dan Sungai Banyuasin yang berfungsi sebagai penyalur limpasan air (runoff) dari hulu menuju laut melalui Sungai Lalan dan Sungai Banyuasin.

62 | Reflis; Reklamasi dan Restorasi Ekologi Tanjung Api - api ... 


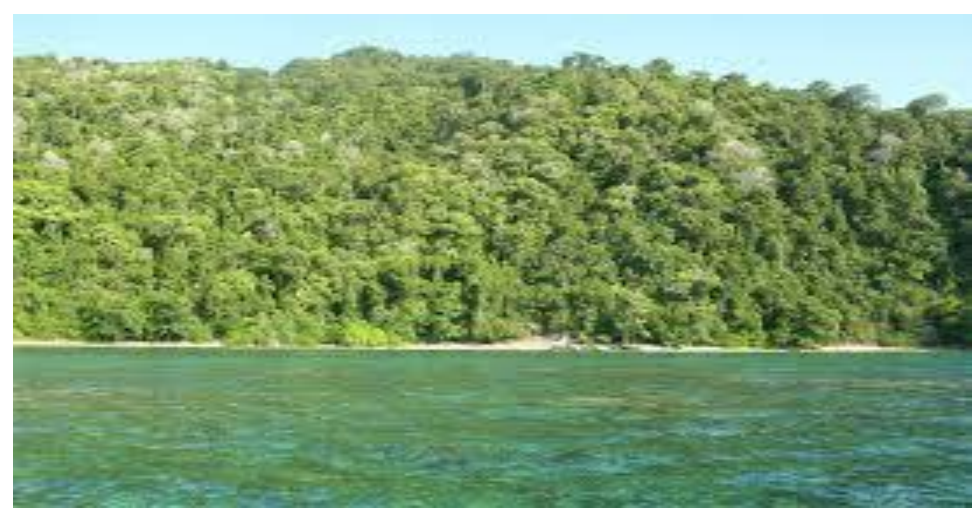

Gambar 3.

Kawasan Mangrove Tanjung Api-Api

(Sumber : Panorama, 2013 dalam Palembang Pos 2013)

Kawasan reklamasi Tanjung Api-Api (Gambar 3) merupakan Hutan Bakau (mangrove) bagian dari lahan basah (wetland). Lahan basah adalah salah satu ekosistem yang paling penting di bumi karena kondisi hidrologi yang unik dan perannya sebagai zona peralihan antara sistem daratan dan perairan (Mitsch dan Gosselink, 2011). Lahan basah, sebagai zona peralihan antara tanah dan air, memberikan perlindungan alami terhadap banjir ekstrim, sebagai simpanan air tawar, penyimpanan karbon jangka panjang serta memiliki keanekaragaman hayati yang tinggi. Namun, banyak lahan basah, khususnya dataran banjir sungai, delta dan muara, telah terdegradasi akibat aktivitas manusia (Verhoeven et al., 2006 dalam Basri dan Kasuri, 2013). Menurut Suweda (2013), karateristik tanah-tanah di lahan basah sangat spesifik terkait dengan sifat fisik lingkungannya, seperti kondisi hidrotopografinya yang datar atau berupa cekungan (depresi), curah hujan tinggi, suhu tinggi, kelembaban tinggi, pengatusan (drainase) dan tata airnya jelek.

Menurut Alikodra (1999), ekosistem hutan mangrove memiliki beberapa sifat kekhususan, yakni letak hutan mangrove terbatas pada tempat tertentu, peranan ekologis ekosistem hutan mangrove bersifat khas, berbeda dengan peran ekosistem hutan lainnya, dan hutan mangrove memiliki potensi hasil yang bernilai ekonomis tinggi, serta hutan mangrove sebagai sumberdaya alam yang dapat dipulihkan pendayagunaan-nya.

Basyuni (2002); Indira dan Birowo (2013) mengatakan, tekanan populasi, pengelolaan yang tidak memperhatikan aspek kelestarian, perkembangan industri dan perkotaan merupakan penyebab utama terhadap kerusakan hutan mangrove. Dengan meningkatnya populasi, lahan produksi semakin berkurang sehingga hutan mangrove dikonversi menjadi lahan pertanian, pertambakan (aquaculture), bahan bakar, dan tujuan lainnya. Penurunan kualitas dan kuantitas hutan mangrove mengakibatkan menurunnya kualitas biofisik ekosistem hutan 
mangrove dan lingkungan sekitarnya, seperti kerusakan fisik pantai (erosi dan abrasi), hilangnya habitat burung, banjir dan menurunnya produktivitas perairan (mangrove dan padang lamun), dampak perubahan iklim global, sedimentasi, serta terbatasnya sarana dan prasarana di wilayah pesisir dan pulau-pulau.

Kerusakan hutan mangrove akibat dari reklamasi kawasan Tanjung ApiApi perlu segera dihentikan dengan mengadakan kegiatan konservasi bahkan merestorasi dengan mengembalikan dan menata kembali yang mengalami kerusakan. Kegiatan konservasi dan restorasi hutan mangrove tidak hanya sekedar untuk melindungi dan melestarikan spesies serta menyediakan obyek wisata (ecoturism), tetapi harus pula berfungsi untuk meningkatkan kondisi sosial ekonomi masyarakat sekitarnya dalam konteks pembangunan berwawasan lingkungan. Membangun hutan mangrove adalah membangun suatu inti bagi tercapainya pembangunan berwawasan lingkungan yang tujuan pokoknya adalah meningkatkan kondisi sosial dan ekonomi masyarakat dan melakukan penanaman kembali hutan mangrove yang telah rusak. Berarti hutan mangrove merupakan salah satu bagian yang sangat penting dari seluruh sistem pembangunan daerah (Alikodra, 1999).

Karena adanya perbedaan kontur tanah wilayah Tanjung Api-Api akibat dari reklamasi hutan mangrove (Gambar 4), maka aliran arus ombak juga akan berubah dan dikhawatirkan menyebabkan sedimentasi dan abrasi besar-besaran yang akan terjadi di pesisir pantai timur Sumatera Selatan. Dalam pasal 37 ayat (2) Keputusan Presiden Republik Indonesia No. 32 tahun 1990, dijelaskan bahwa di dalam kawasan suaka alam dan kawasan cagar budaya dilarang melakukan kegiatan budidaya apapun, kecuali kegiatan yang berkaitan dengan fungsinya dan tidak mengubah bentang alam, kondisi penggunaan lahan serta ekosistem alami yang ada. Peraturan Presiden Republik Indonesia Nomor 122 Tahun 2012 tentang Reklamasi Di Wilayah Pesisir Dan Pulau-Pulau Kecil Pasal 26, menjelaskan pelaksanaan reklamasi wajib menjaga dan memperhatikan: a. Keberlanjutan kehidupan dan penghidupan masyarakat; b. Keseimbangan antara kepentingan pemanfaatan dan kepentingan pelestarian fungsi lingkungan pesisir dan pulau-pulau kecil; dan c. Persyaratan teknis pengambilan, pengerukan, dan penimbunan material.

64 | Reflis; Reklamasi dan Restorasi Ekologi Tanjung Api - api ... 


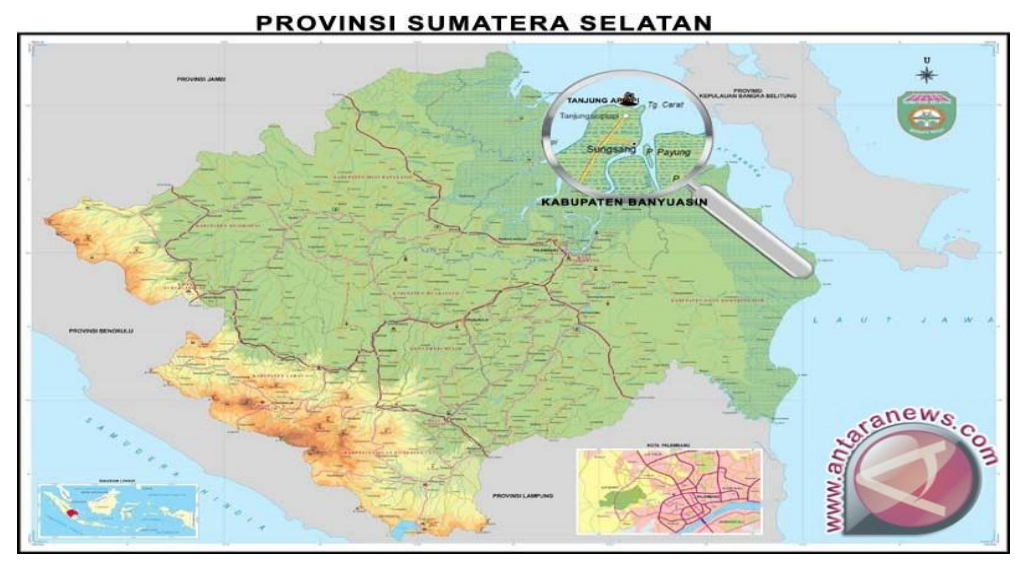

Gambar 4.

Kawasan Reklamasi Tanjung Api-Api (Sumber Antaranews, 2014)

Untuk mereklamasi kawasan Tanjung Api-Api dibutuhkan banyak tanah urugan dengan cara mengepras bukit yang ada di Sumsel dan Bangka Belitung (Babel). Kegiatan ini jelas akan merusak ekosistem di dalamnya. Walaupun pemerintah Provinsi Sumsel bersikeras terhadap dampak positif yang akan diberikan, namun tidak dapat dipungkiri bahwa tindakan reklamasi tersebut memiliki dampak negatif yang justru cenderung lebih banyak.

Jelas terlihat disini, bahwa urgensi reklamasi yang dilakukan pada kawasan Tanjung Api-Api belumlah menjadi hal utama dalam pembangunan, hal itu selain karena faktor lingkungan hidup, dan adanya kawasan hutan bakau. Namun, menurut Badan Koordinasi Penanaman Modal Provinsi Sumatera Selatan (2011) bahwa pembangunan pelabuhan Tanjung Api-Api di Provinsi Sumatera Selatan dilatarbelakangi oleh adanya kebutuhan pelabuhan baru untuk menggantikan peranan Pelabuhan Boom Baru yang saat ini dinilai memiliki sejumlah permasalahan, seperti: a) Jarak ke ambang luar/muara relatif jauh $( \pm 60 \mathrm{mil}=108 \mathrm{~km}) ; \mathrm{b})$ Kedalaman alur sangat tergantung dengan pasang surut; c) Hanya dapat dilayari selama 6 jam per hari (ketika pasang naik) oleh kapal yang memiliki draft $<7 \mathrm{~m}$ dan kapasitas <10.000 GT (Gross Tonage); d) Sedimentasi sangat tinggi $\pm 2,5$ juta $\mathrm{m} 3$ per tahun, sehingga membutuhkan dana 30 milyar per tahun untuk pengerukan demi tercapainya kedalaman -6 MLWS (Meter Lower Water Spring); e) Sulit dilakukan pengembangan karena lokasi pelabuhan berada di pemukiman penduduk dan adanya situs bersejarah, selain itu kolam pelabuhan sulit diperluas karena terbatas oleh lebar sungai; $\mathrm{f}$ ) Alternatif pengganti Pelabuhan Boom Baru hanya ada di kawasan Tanjung ApiApi (tidak ada alternatif wilayah lain); g) Pelabuhan Boom Baru sulit untuk dijadikan pelabuhan utama di Sumatera Selatan yang berfungsi sebagai "outletinlet" hasil produksi komoditas strategis/andalan Sumatera Selatan: migas, batu bara, karet, minyak $\mathrm{CPO}$, pupuk, semen, kayu olahan, pulp, pertanian serta produk lainnya. 
Luas kawasan mangrove di sekitar wilayah Tanjung Api-Api dan Taman Nasional Sembilang kurang lebih 12.000 ha. Pada perencanaan reklamasi kawasan untuk pengembangan Pelabuhan Tanjung Api-Api hanya seluas \pm 600 ha $(5 \%)$, sementara manfaat yang ditimbulkan dengan adanya pembukaan pelabuhan sangat besar dan mempunyai prospek internasional. Pembangunan pelabuhan Tanjung Api-Api meliputi pelabuhan laut dan pelabuhan penyeberangan dengan luas area 122 ha dan biaya investasi Rp 8,00 triliun. Alternatif lahan untuk pelabuhan Tanjung Api-Api, yaitu (a) alternatif-1 di lahan yang sudah mendapatkan persetujuan Menteri Kehutanan seluas 600 ha dan (b) di atas lahan reklamasi seluas \pm 2.250 ha (Badan Koordinasi Penanaman Modal Provinsi Sumatera Selatan, 2011).

Reklamasi Tanjung Api-Api bertujuan untuk pengembangan Kawasan Strategis Ekonomi Khusus Tanjung Api-Api (Lihat Gambar 5), yang akan diperuntukan:1) Pengembangan kawasan Industri Terpadu; 2) Pelabuhan/terminal general kargo; 3) Pelabuhan laut; 4) Pelabuhan penyeberangan; 5) 1 (satu) unit stock pile batubara; 6) Pelabuhan peti kemas; 7) Pelabuhan/terminal curah cair (CPO/BBM/migas/pupuk/semen); 8) Pengembangan kawasan perkantoran; 9) Pengembangan kawasan Permukiman; 10) Pengembangan fasilitas umum sosial-ekonomi; 11) Pengembangan jaringan utilitas pendukung kegiatan pelabuhan, industri dan permukiman; 12) Pengembangan jaringan transportasi (Badan Koordinasi Penanaman Modal Provinsi Sumatera Selatan, 2011).

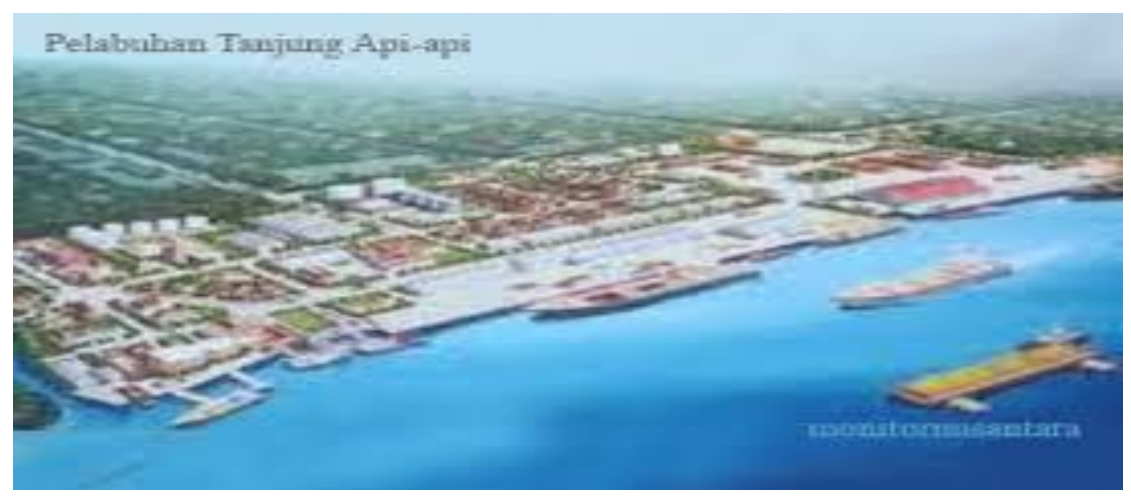

Gambar 5.

Kawasan Pelabuhan Tanjung Api-Api (Sumber: Bentang Alam, 2014 dalam Palembang Pos, 2014)

66 | Reflis; Reklamasi dan Restorasi Ekologi Tanjung Api - api ... 


\section{Restorasi Ekologi pada Kawasan Reklamasi Tanjung Api-Api dan Daerah Aliran Sungai (DAS) Musi bagian Hilir.}

Kawasan reklamasi Tanjung Api-Api adalah muara akhir dari Daerah Aliran Sungai (DAS) Musi yang berhadapan langsung dengan wilayah laut, memiliki fungsi lingkungan sebagai penyalur limpasan air dari daratan menuju laut. Muara merupakan sumberdaya alam, tempat tinggal berbagai biota air dan ikan. Berbagai jenis burung, mamalia, ikan, dan satwa liar lainnya tergantung pada habitat muara sebagai tempat tinggal, sumber makanan, dan bereproduksi. Banyak organisme laut, termasuk berbagai spesies ikan sangat bergantung pada muara untuk pengembang-biakan/pemijahan, sehingga muara dikenal dengan nurseries of the sea. Di wilayah ini, pengaruh air pasang surut (tidal wet-land) sangat kuat, yaitu lahan basah yang langsung dipengaruhi oleh pasang air laut/salin. Lahan gambut pada kawasan reklamasi Tanjung Api-Api biasanya berupa tanah mineral, dan masalah utamanya adalah salinitas tanah yang tinggi akibat intrusi air laut/asin ke daratan (Suriadikarta, 2009).

Nazami, Hairani dan Indrayati (2012), berdasarkan fisik kritis perwilayahan, dengan terdegradasinya kawasan sempadan sungai, untuk itu upaya pemulihan peranan fungsi ekosistem (restorasi ekologi) kawasan sempadan sungai dinilai strategis. Hal ini mengingat bahwa restorasi ekologi merupakan manajemen konservasi dalam mengembalikan habitat atau ekosistem tertentu ke suatu kondisi semirip mungkin dengan keadaan sebelum terjadi degradasi. Waryono (2002), restorasi ekologi adalah proses pemulihan suatu ekosistem yang telah menurun, rusak, atau hancur secara alami. Basri dan Kasuri (2013) mendefinisikan, restorasi merupakan proses yang intens dalam membantu pemulihan dan pengelolaan integritas ekologi suatu ekosistem yang rusak, termasuk berbagai variabel keragaman hayati penting, struktur dan prosesproses ekologi pada konteks sejarah dan kewilayahan, serta kelestarian praktikpraktik budaya.

Waryono $\mathrm{T}$ (2002), langkah awal yang harus ditempuh dalam merumuskan implementasi pengelolaan kawasan reklamasi Tanjung Api-Api sebagai wilayah bantaran sungai, perlu menetapkan unit-unit perencanaan yang rasional dan mampu mengakomodasikan pemulihan peranan fungsi jasa ekosistemnya melalui: (a) pemberdayaan habitat vegetasi riparian, (b) kajian dasar atas peranan fungsi jasa biologis, hidrologis dan ekologisnya, (c) serta mengkaji secara mendalam terhadap nilai kualitas kawasan reklamasi, termasuk kajian potensi baku habitat dan kesesuaian jenisnya, sebagai dasar acuan dalam penyusunan rancangan model restorasi ekologi bantaran sungai. 


\section{SIMPULAN DAN SARAN}

\section{Simpulan}

Dari hasil pembahasan di atas dapat ditarik kesimpulan, yaitu: 1) Dampak kegiatan reklamasi Tanjung Api-Api menurunkan kualitas lingkngan hutan bakau (mangrove) dan Daerah Aliran Sungai (DAS) Musi, namun demi kepentingan umum dengan memperhatikan segala manfaatnya maka reklamasi ini dapat dilanjutkan asal sesuai ketentuan yang berlaku dan memperhatikan aspek yang terkait serta dampak dan manfaatnya; 2) Kerusakan ekosistem akibat reklamasi Tanjung Api-Api cukup mengkhawatirkan, oleh karena itu perlu dilakukan upaya pemulihan melalui restorasi hutan mangrove dan DAS Musi bagian hilir yang terpadu. Restorasi ekologi diharapkan mampu mengembalikan fungsi dan peranan ekosistem mangrove dan DAS Musi bagian hilir.

\section{Saran}

Para pelaku pembangunan harus mempertimbangkan rencana kawasan reklamasi Tanjung Api-Api yang melibatkan setiap lapisan masyarakat dengan bepegang teguh terhadap prinsip-prinsip pembangunan, seperti prinsip kebersamaan, berkeadilan, berkelanjutan, berwawasan lingkungan, serta kemandirian dengan menjaga keseimbangan antara manusia, aktivitas ekonomi dan lingkungan.

\section{DAFTAR PUSTAKA}

Alikodra, H.S. 1999. Implementasi Konservasi Hutan Mangrove di Indonesia. Makalah pada Raker Pengelolaan Pesisir dan Hutan di Indonesia yang diselenggarakan pada 18 Mei 1999 oleh Direktorat Jenderal Bangda Depdagri. Jakarta

Badan Koordinasi Penanaman Modal. 2011. Potensi Investasi Provinsi Sumatera Selatan. Palembang

Basri, H. Dan Kasuri, A.R. 2013. Rencana Restorasi Rawa Wetland Restoration Plan. Project Implementation Unit - Studi Ekosistem Rawa Tripa Universitas Syiah Kuala. Banda Aceh

Basyuni, M.2002 Panduan Restorasi Mngrove Yang Rusak (Degrated). Fakultas Pertanian Program Ilmu Kehutanan-Universitas Sumatera Utara. Medan

Huda M.C. 2013. Pengaturan Perizinan Reklamasi Pantai Terhadap Perlindungan Lingkungan Hidup. Jurnal Perspektif. XVIII (2) Tahun 2013 Edisi Mei. Surabaya.

Indira M. Dan Birowo. M.A. 2013. Analisis Isi pada Berita Lingkungan dalam Pemberitaan Kasus Reklamasi Teluk Benoa Bali. Objektivitas Berita

68 | Reflis; Reklamasi dan Restorasi Ekologi Tanjung Api - api ... 
lingkungan Hidup di Surat Kabar. Surat Kabar Bali Post Periode 27 Juni 2013 - 18 Agustus 2013). Program Studi Ilmu Komunikasi Fakultas Ilmu Sosial dan Ilmu Politik.Universitas Atma Jaya Yogyakarta. Yogyakarta

Mitsch, W.J., and Gosselink, J. G. 2011. Wetlands. Ecological Studies, 190, John Wiley \& Sons.

Nazami, Hairani dan Indrayati, 2012. Prospek Pengembangan Penataan Lahan Sistem Surjan di Lahan Rawa Pasang Surut. Balai Penelitian Pertanian Lahan Rawa (Balittra). Jurnal Agrovigor 5(2):113 - 120. Banjar baru.

Palembang Pos. 2013. Percepat Pembebasan Lahan. Harian Palembang Pos Monday, 06 May 2013; Palembang.

Palembang Pos. 2014. Pemerintah Menetapkan II Kawasan Ekonomi Khusus (KEK) Palembang

Soegiarto, A. 2004. The Mangrove Ecosystem in Indonesia : Its Problems and Management in H.J. Teas (ed). Physiology and Management of Mangrove. W. Jung Publishers, The Hague. P69 - 78.

Soemodihardjo, S., R. Ongkosono, \& A. Abdullah. 2006. Diskusi Panel Daya guna dan Batas Lebar Jalur Hijau Hutan Mangrove. Panitia Program MAB Indonesia - LIPI. Proyek Penelitian Lingkungan Hidup. P17 - 22.

Suganda, E. Yatmo, Y.A. dan Atmodiwirjo P. 2009. Pengelolaan Lingkungan dan kondisi Masyarakat Pada Wilayah Hilir Sungai. Jurnal Makara, Sosial Humaniora. 13(2) 143 - 153.

Suriadikarta, D.A. 2009. Pembelajaran Dari Kegagalan Penanganan Kawasan PLG Sejuta Hektar Menuju Pengelolaan Lahan Gambut Berkelanjutan . Balai Penelitian Tanah. Naskah disarikan dari bahan Orasi Profesor Riset yang disampaikan pada tanggal 6 Agustus 2009. Bogor.

Suweda I.W. 2013. Analisa Dampak Bangkitan Lalu Lintas Terhadap Rencana Kawasan Reklamasi Teluk Benoa Bali. Konferensi Nasional Teknik Sipil 7 (KoNTekS 7).Universitas Sebelas Maret (UNS). Surakarta. 24-26 Oktober 2013

Waryono, T. 2002. Konsep Restorasi Ekologi Kawasan Penyangga Sempadan Sungai Di DKI Jakarta. Seminar Nasional Evaluasi Pasca dan Rancang Tindak Penanggulangan Banjir Wilayah Perkotaan. Kedutaan Belanda (Kuningan Jakarta), 12 Juni 2002, Kerjasama Dept. Kimpraswil, Masyarakat Air Indonesia, dan Kedutaan Belanda. Jakarta

Widjanarko,A. 2013. Arah Dan Kebijakan Pembangunan Nasional Infrastruktur Pekerjaan Umum dan Permukiman. Sebagai Kuliah Umum Karya Siswa Beasiswa Pendidikan dan Vokasi Tahun 2013. Kerjasama 
Kementerian PU \& Mitra Perguruan Tinggi Sekretaris Jenderal Kementerian PU Republik Indonesia. Jakarta

Woinarski L.2002. Pulau Serangan: Dampak Pembangunan pada Lingkungan dan Masyarakat. Universitas Muhamadiyah Malang kerjasama dengan Australian Consotium For In-Country Indonesian Studies. Malang.

\section{PERATURAN DAN PERUNDANG-UNDANGAN}

Keputusan Presiden Republik Indonesia Nomor 32 Tahun 1990. Tentang Pengelolaan Kawasan Lindung

Peraturan Presiden Republik Indonesia Nomor 122 Tahun 2012, Tentang Reklamasi Di Wilayah Pesisir dan Pulau-Pulau Kecil

Peraturan Menteri Pekerjaan Umum No. 40/PRT/M/2007. Modul Terapan Pedoman Pedoman Perencanaan Tata Ruang Kawasan Reklamasi Pantai

Peraturan Presiden No. 51. (2014). Tentang Penetapan Kawasan Ekonomi Khusus (KEK) Tanjung Api- Api

70 | Reflis; Reklamasi dan Restorasi Ekologi Tanjung Api - api ... 